\title{
KNJIŽNICA KAO PROSTOR FLANERIJE
}

\author{
THE LIBRARY AS FLÂNERIE SPACE
}

\author{
Bernadica Ivanković \\ Gradska knjižnica Subotica \\ bernadica@gmail.com \\ Nevena Mlinko \\ Gradska knjižnica Subotica \\ nevenashce@gmail.com
}

UDK / UDC 028-053.6(497.11)

Stručni rad / Professional paper

Prihvaćeno / Accepted: 23. 4. 2017.

\section{Sažetak}

U suvremenom svijetu u kojem živimo knjiga i knjižnica kao prostor znanja, umjetnosti i kreativnosti trebaju biti prošireni. Tim povodom Gradska knjižnica Subotica osniva čitateljski klub za tinejdžere pod nazivom Flâneuri gdje polazeći od knjige i riječi želi interdisciplinarnim pristupom brisati granice među umjetnostima te klasičnom i virtualnom šetnjom potaknuti kod mladih čitatelja gastronomiju oka i duha. Flâneur je radoznali promatrač grada koji luta s jednim ciljem - da doživi neočekivano, otkrije nepoznato, iskusi nešto novo i stvori nešto svoje. Zato je flâneur istodobno pustolov i pjesnik, promatrač i humorist, istraživač i filozof, umjetnik koji otkriva i uobličava svijet na različite načine.

Ključne riječi: flâneuri, mladi, čitanje, šetnja, Gradska knjižnica Subotica

\section{Summary}

In the modern world in which we live today, books and libraries, as places of knowledge, art and creativity, need to be expanded in all directions. In order to follow this

Vjesnik bibliotekara Hrvatske 60, 1(2017), 183-191

ISSN 0507-1925

(C) VBH 2017. 
trend, the City Library in Subotica has established a readers' club for teenagers called The Flâneurs with the aim to erase the boundaries between arts and through an interdisciplinary approach, starting from books and words, through a virtual tour inspire gastronomy of the eye and the mind in young readers. A flâneur (from the French flâneur) is a curious observer who wanders through the city with one goal: to experience the unexpected, to discover the unknown, to experience something new, but also to create something new. A flâneur is an adventurer and a poet at the same time, a humorist and an observer, a researcher and a philosopher. In a word, a flâneur is an artist who reveals and shapes the world in different ways.

Keywords: flâneurs, young, reading, walking, City Library Subotica

\section{Uvod}

Градска библиотека Суботица / Szabadkai Városi Könyvtár / Gradska knjižnica Subotica (u daljnjem tekstu Gradska knjižnica Subotica) ${ }^{1}$ u Republici Srbiji je najstarija ustanova kulture u gradu. Utemeljena je 1890. godine i svakodnevno funkcionira te pruža usluge korisnicima na tri službena jezika grada - na srpskom, mađarskom i hrvatskom jeziku. ${ }^{2}$ Javna je knjižnica lokalni centar informacija koji omogućava da sve vrste znanja i informacija budu odmah na raspolaganju korisnicima, kaže se u manifestu IFLA-e/UNESCO-a za javne knjižnice iz 1994. ${ }^{3}$ Uz to je važno da sve starosne grupe u knjižnicama mogu pronaći građu i informacije koje odgovaraju njihovim potrebama. Tinejdžeri su kao specifična i zahtjevna skupina ljudi na prijelazu iz djetinjstva u odraslo doba dugo bili zapostavljeni, odnosno nisu bili prepoznati kao posebna korisnička skupina. Značajan pomak dogodio se tek sredinom 20. stoljeća, najprije u SAD-u i Njemačkoj, a sada su pomaci vidljivi i u našoj zemlji, odnosno u zemljama regije. Prvo izdanje Smjernica za knjižnične usluge za mladež IFLA je objavila 1996. godine. To izdanje neznatno je promijenjeno 2001. godine, a iste je godine objavljen i hrvatski prijevod u izdanju HKD-a. ${ }^{4}$ Iako je prošlo petnaest godina od objavljivanja dopunjenih smjernica, što je dugo razdoblje te su vidljive brojne promjene, osnovne upute i svrha knjižničnih usluga za mladež ostale su nepromijenjene. Prema Manifestu UNESCO-a

1 Odlukom Gradske skupštine službeni je naziv knjižnice trojezičan (Градска библиотека Суботица / Szabadkai Városi Könyvtár / Gradska knjižnica Subotica) i nema kraći oblik.

2 Odlukom Skuštine općine Subotice od 20.12. 2001. godine ponovno je uveden hrvatski jezik kao službeni jezik Subotice.

3 Međunarodni i bibliotečki manifesti : IFLA/UNESCO. Beograd : Bibliotekarsko društvo Srbije, 2014.

4 Smjernice za knjižnične usluge za mladež : prerađeno izdanje Smjernica koje je 1996. objavio Stalni odbor Sekcije knjižnica za djecu i mladež. Zagreb : Hrvatsko knjižničarsko društvo, 2009. 
narodne knjižnice su elementarni i izuzetno snažni čimbenici obrazovanja, kulture i informiranja društva. Tinejdžerske skupine prepoznate su kao kritične jer se u toj dobi prestaje čitati neobavezna literatura i stoga im je potrebno posvetiti posebnu pozornost. Dinamika psihičkog i emocionalnog razvoja mladih ljudi, uz učestale promjene zanimanja, trebala bi biti praćena od strane knjižničara i drugih stručnjaka te potpomognuta i usmjerena adekvatnim i raznovrsnim knjigama.

U Gradskoj knjižnici Subotica postoji bogata ponuda programa za djecu predškolske i osnovnoškolske dobi. Pored kontinuiranih posjeta radi upoznavanja knjižnice, satova obrade lektire i gostovanja pisaca, izdvajamo tri čitateljska kviza: „Čitam i skitam”, „Čitanjem do zvijezda” i Nacionalni kviz za poticanje čitanja Knjižnica grada Zagreba. Uz raznovrstan program za djecu i odrasle ${ }^{5}$, ostao je upražnjen programski prostor za tinejdžere. Nakon rasta uz knjižnicu i u knjižnici, stasala je kritična skupina mladih kojima je trebalo ponuditi nov pogled i doživljaj knjižnice kako bi bili zadržani u knjižničnim odajama kao vlastitom i ugodnom prostoru rasta i napretka. Tako je koncem 2015. godine, nakon pilot-projekta noćenja u knjižnici ${ }^{6}$, pokrenut čitateljski klub pod nazivom Flâneuri.

\section{Naziv, cilj i metode rada čitateljskog kluba Flâneuri}

Flâenur ${ }^{7}$ je riječ francuskog podrijetla i odnosi se na točno određenu pojavu s konca XIX. i početka XX. stoljeća. Flâneur je tipični impresionistički proizvod urbane kulture i estetike ulice koji je u svjetsku književnost uveo Baudelaire, a u Hrvata Matoš. Figura flâneura je figura dokoličara - promatrača i radoznalog šetača. Nekoliko je osobito važnih momenata u poimanju flanerije za funkcioniranje čitateljskog kluba, a to su grad, stvaralaštvo i šetnja.

Simbol flanerije je grad Pariz. Louis Huart u Psihologiji flaneura zapisuje da je „Pariz idealno mjesto za flaniranje, a flâneur najsretniji čovjek na svijetu”. Ono što je Pariz bio umjetnicima početkom XX. stoljeća - kulturno i umjetničko obilje, kako Matoš zapisuje „ognjište estetičkih novotarija, ognjište ljepote, umjetnosti, literature" - poželjeli smo da to knjižnica postane današnjim mladima. Matoš je iz

5 Za odrasle su organizirani okrugli stolovi s popratnim manifestacijama Dani Balinta Vujkova, Književni KIŠobran, Dani Dezsőa Kosztolányija te gostovanja pisaca. Više o aktivnostima Gradske knjižnice Subotica možete čitati na mrežnoj stranici knjižnice-subiblioteka.rs.

6 Naziv programa bio je „Provedi noć s knjigom”, a realiziran je u srpnju 2015. godine. Više o tome u Tinejdžeri - zahtevni korisnici i biblioteke za nove generacije : zbornik radova sa međunarodnog stručnog skupa održanog u Lazarevcu 15. i 16. septembra 2015. Lazarevac : Biblioteka „Dimitrije Tucović”, 2015. Citirano prema: Ivanković, Bernadica. Provedi noć s knjigom. // Tinejdžeri - zahtevni korisnici i biblioteke za nove generacije : zbornik radova sa međunarodnog stručnog skupa održanog u Lazarevcu 15. i 16. septembra 2015. / urednik Milica Matijević. Lazarevac : Biblioteka „Dimitrije Tucović”, 2015. Str. 19-28.

7 Svi navedeni citati u poglavlju i interpretiranje pojma flâneura i flanerije pisani su prema tekstu Flaneur u knjizi: Nemec, Krešimir. Čitanje grada. Zagreb : Naklada Ljevak, 2010. Str. 75-93. 
Zagreba, koji je imao šezdesetak tisuća stanovnika, došao 1899. u dvomilijunski Pariz i sve mu je djelovalo fascinantno - a vjerujemo da isto tako i knjižnica danas treba i može djelovati na mlade ljude koji dođu u nju. Analogija između knjižnice i grada Pariza bila je osnovna nit vodilja u odabiru naziva čitateljskog kluba. Željeli smo mladima knjižnicu predstaviti ne kao javni prostor koji podređuje korisnike, nego kao prostor koji flâneuri svojom šetnjom oživljavaju, oblikuju i, na koncu, predstavljaju. Vođeni mislima Lehana, koji je pisao o pojmu flâneura, željeli smo kod budućih članova čitateljskog kluba izazvati osjećaj nezadovoljstva jer knjižnica, poput grada flâneurima, nudi puno više iskustava nego što su oni u stanju asimilirati.

Druga važna značajka za rad našeg čitateljskog kluba, koju sadržava i pojam flanerije, jest stvaralaštvo. U susretu s gradom flâneur nije indiferentan, nego otvoren novim saznanjima i doživljajima posredstvom kojih, pored bogatstva ponude grada, otkriva sebe kao pustolova, istraživača, pjesnika, promatrača, humorista, filozofa, umjetnika itd. U svakom susretu s knjigom u čitateljskom klubu željeli smo da mladi stvore vlastiti duhovni proizvod kojim će oplemeniti svoj život i živote drugih. Konkretan cilj bio je pustiti mlade da dožive sadržaj knjižnice po vlastitoj mjeri u slobodi stvaralaštva bilo kroz pisanu ili izgovorenu riječ, crtež, fotografiju, plakat ili neki drugi vid izričaja. Poticanje kreativnosti i razigranosti duha vodilo bi razvijanju ,gastronomije oka" o kojoj je, vezano uz flaneriju, pisao Balzac u Fiziologiji braka.

Osnovna metoda rada čitateljskog kluba Flâneuri, koja se odnosi na prostornu komponentu knjižnice, jest šetnja. Matoš definira flaneriju kao „Zabavnu šetnju nepoznatim putom" koju karakteriziraju uživanje, artistička zabava, stvaralaštvo i sloboda. Šetnja je realizirana doslovno i u prenesenom značenju kao npr. šetnja knjižnicom i šetnja kroz literaturu, virtualna šetnja, šetnja kroz grad i kroz povijest grada te druge vrste šetnji.

Članovi čitateljskog kluba Flâneuri mogu biti svi zainteresirani tinejdžeri u dobi od 14 do 19 godina, dakle učenici završnih razreda osnovne škole (sedmi i osmi) te srednjoškolci. Susreti se realiziraju jednom mjesečno u vidu radionica u dogovorenim terminima na različitim lokacijama, sukladno temi i ,šetnji” koja je planirana. Program se odvija na hrvatskom jeziku.

Ta osnovna pravila postavljena su na samom početku osnutka Flâneura, a s vremenom su dopunjavana sukladno potrebama, interesima i drugim okolnostima rada.

\section{Susreti čitateljskog kluba Flâneuri}

Gradska knjižnica Subotica, kao i većina drugih knjižnica, ima problem nedostatka prostora te, iako postoje želje i opravdane potrebe, nema formiran odjel za 
tinejdžere. Ta osjetljiva populacija najčešće ne osjeća pripadnost ni Dječjem odjelu ni Odjelu za odrasle, jer za prvi se čine prestarima, dok ih drugi još ne privlači. U IFLA-inim Smjernicama za knjižnične usluge za mladež može se pročitati da je potrebno na temelju jedinstvenih potreba mladih u svakoj knjižnici omogućiti prijelaz s usluga za djecu na usluge za odrasle te im osigurati prostor koji će biti namijenjen isključivo mladima. Taj prostor trebao bi mladima biti privlačan te odražavati njihov životni stil. ${ }^{8}$ Iako subotička knjižnica iz više razloga trenutačno nije u mogućnosti ispuniti tu preporuku, uvijek se nastoji pronaći rješenje. Kontinuiranim i kvalitetnim radom s djecom izdvojila se jedna skupina koja je odrastajući uz knjigu i knjižnicu prerasla aktualne programe za djecu te postala spremna za novu razinu svojstvenu svojoj dobi, predznanju i potrebama. Ideja je bila ponuditi mladima čitateljski klub, no poznajući osobitosti te specifične populacije, bilo je potrebno vrijeme da tu ideju prihvate kao svoju kako bi se u nju trajno uključili. Prilikom organiziranja pilot-programa „Provedi noć s knjigom” mladi su izrazili želju za nastavkom aktivnosti. Dogovoreno je da će tijekom jeseni biti pokrenut novi vid druženja s knjigom za njihovu dob koji će biti drugačiji i koji će sami moći kreirati. Tijekom jeseni u više se navrata razgovaralo na tu temu, da bi krajem godine ideja sazrela među njima te je pokrenuta inicijativa za formiranje čitateljskog kluba za tinejdžere. Nisu otkriveni svi detalji, a hranjena je njihova želju za okupljanjem oko knjige.

Poznato je da mladi aktivno žive u virtualnom svijetu, pa smo izradili plakat koji je zaintrigirao pojedince (slika 1). Svakodnevno smo objavljivali po informaciju ili sliku na društvenim mrežama te pozivali mlade da nam se pridruže u avanturi i postanu flâneuri. Iste informacije bile su im dostupne i posredstvom škole, na oglasnim pločama i odjelima knjižnice, u medijima i drugdje gdje smo znali da se okupljaju mladi.

S obzirom na to da pojam flâneur nije bio poznat ni korišten u našoj sredini, potencijalnim članovima čitateljskog kluba ponudili smo dodatne smjernice za razumijevanje i objašnjenja, ostavljajući mogućnost mladima da pojam flâneur dožive osobno.

„Tko je flâneur i što on radi?

Flâneur je radoznali promatrač grada koji luta s jednim ciljem - da doživi neočekivano, otkrije nepoznato, iskusi nešto novo i stvori nešto svoje. U čitateljskom klubu istraživat ćemo urbanu i suvremenu književnost, a kretat ćemo se i kroz stvarne gradove, pisat ćemo i interpretirati viđeno i pročitano vođeni idejama slobode u improvizaciji i artističke zabave. Zato je flâneur istodobno pustolov i pjesnik, promatrač i humorist, istraživač i filozof, umjetnik koji otkriva grad na različite načine.

8 Smjernice za knjižnične usluge za mladež / glavna urednica Ana Barbarić. Zagreb : Hrvatsko knjižničarsko društvo, 2009.. 
Ako ste se u nečemu napisanom prepoznali ili vam se ideja svidjela, priključite se čitateljskom klubu flâneuri."

Iako je bilo pozitivnih reakcija, do posljednjeg trenutka nismo znali koliko će se mladih odazvati našem pozivu. Na prvom susretu okupilo se trinaestero tinejdžera koji su i danas članovi čitateljskog kluba. Svojim oduševljenjem uspjeli su animirati još nekolicinu učenika te sada Flâneuri broje dvadeset članova koji se mjesečno okupljaju. Čitateljski klub vode informatorice knjižnice uvažavajući želje i interese svih članova. Svaki je sastanak tematski i ima svoj naziv, cilj i metode rada koji se značajno razlikuju od susreta do susreta.

Prvi susret čitateljskog kluba Flâneuri održan je 12. ožujka 2016. godine u čitaonici Gradske knjižnice Subotica s ciljem njegova formiranja. Nakon nekoliko igrica međusobnog upoznavanja, mladi čitatelji na interaktivan su način utvrdili što znači pojam flâneur putem asocijacija vezanih uz ključne pojmove flanerije kao što su grad, knjiga, istraživači, umjetnost i druženje. Doznali su i koji će biti principi rada i sastanaka u klubu. Budući da je šetnja u svakom smislu riječi, bilo ona fizička, virtualna ili otkrivanje nepoznatog, osnovni motiv flâneura, novim članovima čitateljskog kluba ponuđena je šetnja sa subotičkim građanstvom potkraj XIX. i početkom XX. stoljeća posredstvom interaktivne izložbe postavljene u holu knjižnice. Radoznalost i izazov traženja odgovora iz upitnika doveli su flâneure, podijeljene u parove, do kulturnih i povijesnih informacija vezanih uz zlatno doba Subotice. Prošetali su se kroz povijest svoga grada i uočili sve važne trenutke njegova razvitka. Tom prigodom morali su se poslužiti i određenom priručnom literaturom, odnosno rječnicima, ne bi li u potpunosti točno i ispravno shvatili određene pojmove.

Drugi susret čitateljskog kluba Flâneuri imao je temu Put knjige. Održan je 16. travnja 2016. godine van knjižnice, u poznatoj subotičkoj tiskari „Rotografika". Kroz doslovnu šetnju flâneuri su doznali kako nastaje knjiga, od rukopisa do krajnjeg proizvoda koji držimo u ruci, a prošetali su i kroz povijest tiskarstva te se oprobali kao nekadašnji slovoslagači. Za tu šetnju imali su stručno vodstvo iz „Rotografike”.

Treći susret čitateljskog kluba Flâneuri održan je 16. svibnja 2016. godine na Posudbenom odjelu za odrasle Gradske knjižnice Subotica. Tema je bila Recikliranje riječi, što su oni doista i učinili. Riječi koje olako, a prečesto i bez razmišljanja izgovaramo, a koje povređuju druge ljude, ispisali su na papire kako bi ih doslovno reciklirali, odnosno izrezali na dijelove - slova - te pretvorili u lijepe,

9 Gradska knjižnica Subotica : vijesti : čitateljski klub flâneuri [citirano: 2016-11-10]. Dostupno na http://www.subiblioteka.rs/hr/vesti-detaljnije/316/. 
poticajne i afirmativne riječi koje svatko voli čuti. Zaključili su kakva je snaga riječi, bile izrečene ili zapisane, te kako je potrebno puno više vremena da se isprave pogreške njihove olake upotrebe. Sve su to upotpunili i primjerima, prigodnim ulomcima iz domaće i svjetske književnosti, koje su naglas čitali jedni drugima. Kao plod tog susreta nastale su i poticajne riječi koje su zalijepili na stepenicama Odjela za odrasle, čime ne samo da su oplemenili prostor nego su se i ugradili u njega (slika 2). Budući da je tih tjedana knjižnica bila zatvorena za korisnike radi renoviranja i obvezne revizije fonda, mladi čitatelji potrudili su se da prostor knjižnice učine ugodnijim i ljepšim za korisnike kada ponovno bude u funkciji.

Četvrti susret čitateljskog kluba Flâneuri održan je ponovno van knjižnice 10. lipnja 2016. godine, na Međunarodni dan secesije. Potaknuti analogijom Waltera Benjamina kojom izjednačava pasaže i ulice s dokoličarevim stanom te piše kako je flâneur doma među pročeljima kuća, pridružili su se programu obilježavanja Svjetskog dana secesije i šetnji kroz grad „Tragom secesijskih objekata Titusa Mačkovića". Obišli su desetak objekata koje je projektirao poznati Subotičanin krajem XIX. i početkom XX. stoljeća uz plakate koje su izradili učenici Politehničke škole. Tom prigodom bili su i na otvorenju izložbe fotografija Željka Vukelića „Titusova secesija”. Ta iznimna šetnja gradom realizirana je u suradnji s Gradskim muzejom u Subotici koji je organizirao stručno vodstvo za sve zainteresirane građane.

Peti susret čitateljskog kluba Flâneuri održan je po završetku školske godine, 20. srpnja 2016. godine, u čitaonici Gradske knjižnice Subotica. Noćenjem u knjižnici završena je prva godina okupljanja flâneura. Putem Skypea povezali su se s mladima iz Gradske i sveučilišne knjižnice Osijek i razgovarali o omiljenim književnim žanrovima, ljetnim aktivnostima, čitateljskim klubovima, filmovima i knjigama. Uslijedili su i umjetnički performansi na obje strane. Nakon toga flâneuri su se družili s odabranim domaćim i stranim književnicima tragajući za njihovim lokacijama u knjižnici, a sastavili su i vlastite priče koje su dramatizirali i odglumili u improviziranom kazalištu. Nakon zajedničke večere iz improviziranih kreveta pogledali su odabrani film snimljen po knjizi. Za Tu prigodu prekrasnu čitaonicu subotičke knjižnice pretvorili su u veliku spavaonicu (slika 3). Tako su ponovili program „Provedi noć s knjigom” koji je bio i prethodnica osnutku čitateljskog kluba Flâneuri. Zbog ljetnog radnog vremena tijekom trajanja programa knjižnica je bila zatvorena za korisnike, te je peti sastanak flâneura samim time bio još privlačniji i osobitiji.

Projekt „Provedi noć s knjigom” bio je u potpunosti osmišljen za tinejdžersku populaciju. Njime su zadovoljene sve specifične potrebe te grupe mladih ljudi, a 
postignut je i cilj - osnaživanje mladih čitatelja u Subotici i umrežavanje s vršnjacima u Osijeku.

Šesti susret čitateljskog kluba Flâneuri održan je u Gradskoj knjižnici Subotica 24. rujna 2016. godine. Tema susreta bila je „Čitati il ne čitati, pitanje je sada", odnosno, lik i djelo Williama Shakespearea, budući da je 2016. godine obilježavana 400. obljetnica njegove smrti. Kroz šetnju sa Shakespeareom flâneuri su pokušali odgovoriti na neka vječna pitanja o vjerodostojnosti njegova postojanja i spisateljskog rada. Nakon čitanja njegovih drama uslijedile su radionice s javnom prezentacijom dobivenih zaključaka u vidu dramatizacije, plakata i debate.

Sedmi susret čitateljskog kluba Flâneuri održan je u studenom 2016. godine, koncem mjeseca hrvatske knjige, pod sloganom „I mi čitamo 100 na sat”. Sastanak mladih čitatelja priređen je u knjižari „Školska knjiga” u Subotici, dakle, ponovno van knjižnice. Više od dva sata flâneuri su se družili s knjigama koje su međusobno jedni drugima preporučivali te naglas čitali najzanimljivije ulomke po osobnom izboru. Tijekom susreta doznali su i koji su novi naslovi u Školskoj knjizi nakon dvaju sajmova knjiga održanih u Beogradu i Zagrebu. Šetnja kroz književnost vlastitim odabirom potaknula je mnoge članove kluba da posude preporučene naslove (slika 4).

\section{Zaključak}

Brojne su mogućnosti i funkcije javnih knjižnica. Jedna od njih svakako je omogućavanje uspješnog prijelaza mladima iz djetinjstva u odraslu dob. Značajnu pomoć u ostvarivanju tih ciljeva pružaju IFLA-ine smjernice za knjižnične usluge za mladež koje usmjeravaju knjižnice u promicanju pismenosti, cjeloživotnog učenja, informacijske pismenosti i čitanja iz užitka. Današnje, suvremene generacije tinejdžera zahtijevaju suvremene metode rada prilagođene njihovim posebnostima. Stoga osnivanje čitateljskih klubova u svrhu poticanja čitanja mora biti zasnovano na novim principima rada. Flanerija nudi te mogućnosti, jer flâneur je radoznali promatrač grada koji luta s jednim ciljem - da doživi neočekivano, otkrije nepoznato, iskusi nešto novo i stvori nešto svoje. Gradska knjižnica Subotica uspješno provodi aktivnosti novoosnovanog čitateljskog kluba Flâneuri te novim i drugačijim metodama ostvaruje potrebnu komunikaciju s mladima koji u konačnici čitaju iz užitka. Poznato je da djeca i mladi koji čitaju postaju ljudi koji misle. Stoga je važno da knjižnice na vrijeme prilagode, prošire i unaprijede svoje aktivnosti i transformiraju se u prihvatljive centre za mlade. 


\section{LITERATURA:}

Bibliotečke usluge / Dani matičnih biblioteka Srbije 2008 Biblionet. Beograd : Zajednica matičnih biblioteka Srbije; Subotica : Gradska biblioteka : 2008.

Brofi, Piter. Biblioteke u dvadeset prvom veku : nove usluge za informaciono doba. Beograd : Clio, 2005.

Center, Sandra. Kako zavoljeti knjigu i čitanje. Đakovo : Tempo, 2007.

Dani Balinta Vujkova - dani hrvatske knjige i riječi : zbornik radova sa znanstvenih skupova 2013. - 2014. Subotica : Hrvatska citaonica, 2015.

Gradska knjižnica Subotica : vijesti : čitateljski klub flâneuri [citirano: 2016-11-10]. Dostupno na http://www.subiblioteka.rs/hr/vesti-detaljnije/316/.

Ilić, Pavle; Olivera Gajić, Milanka Maljković. Kriza čitanja : kompleksan pedagoški, kulturološki i opštedruštveni problem. Novi Sad : Gradska biblioteka, 2007.

Ivanković, Bernadica. Provedi noć s knjigom. // Tinejdžeri - zahtevni korisnici i biblioteke za nove generacije : zbornik radova sa međunarodnog stručnog skupa održanog u Lazarevcu 15. i 16. septembra 2015. / urednik Milica Matijević. Lazarevac : Biblioteka „Dimitrije Tucović”, 2015. Str. 19-28.

Jovanović, Ivana Arsić. Planeta čitalac : priručnik o razvoju publike u bibliotekama. Pančevo : Gradska biblioteka Pančevo; Beograd : Udruženje Kulturis : 2014.

Međunarodni i bibliotečki manifesti : IFLA/UNESCO. Beograd : Bibliotekarsko društvo Srbije, 2014.

Nemec, Krešimir. Čitanje grada. Zagreb : Naklada Ljevak, 2010.

Smjernice za knjižnične usluge za mladež / glavna urednica Ana Barbarić. Zagreb : Hrvatsko knjižničarsko društvo, 2009.

Stropnik, Alka. Knjižnica za nove generacije : virtualni sadržaji i usluge za mlade. Zagreb : Hrvatsko knjižničarsko društvo, 2013 